\title{
Communities of Code-Switching Connoisseurs
}

Multilingualism in Islamic Sermons in Bangladesh

Max Stille

\section{OpenEdition}

12 Journals

Electronic version

URL: http://journals.openedition.org/samaj/4485

DOI: $10.4000 /$ samaj.4485

ISSN: 1960-6060

Publisher

Association pour la recherche sur l'Asie du Sud (ARAS)

Electronic reference

Max Stille, "Communities of Code-Switching Connoisseurs », South Asia Multidisciplinary Academic Journal [Online], Free-Standing Articles, Online since 01 March 2018, connection on 01 May 2019. URL : http://journals.openedition.org/samaj/4485 ; DOI : 10.4000/samaj.4485

This text was automatically generated on 1 May 2019.

\section{(c) (i) (3)}

This work is licensed under a Creative Commons Attribution-NonCommercial-NoDerivatives 4.0 International License. 


\title{
Communities of Code-Switching Connoisseurs
}

\author{
Multilingualism in Islamic Sermons in Bangladesh
}

Max Stille

\section{EDITOR'S NOTE}

This paper received the Student Research Award by the European Association for South Asian Studies at the 2016 European Conference on South Asian Studies held in Warsaw.

1 This article ${ }^{1}$ considers the rhetoric effects of a co-presence of different linguistic codes in Islamic sermons in contemporary Bangladesh. The sermons are held in gatherings called waz mahfils, ${ }^{2}$ in brightly illuminated and often festive tents, which are typically erected on paddy fields after harvest in rural areas or at street corners and public grounds in cities. Inside the tents, several preachers speak one after the other. They are seated, together with guests of honor and their entourages, on a slightly elevated stage. The exclusively male audience assembles on the ground in front of the stage, which is covered with mats made out of bamboo, cotton, or rarely, on straw. The size of the audience varies a lot, from small gatherings to large mass meetings, but its members are generally involved in the performance by reciting along with the preacher, by uttering affirmative interjections, or by shedding tears. Audience presence, attention, and participation is ensured by frequent call-and-response interactions between the preacher and the audience.

2 Waz mahfils mostly start around sunset on any day of the week outside the rainy season, and continue until around midnight. The sermons are by no means confined to the instructions of ritual commands stressed in Friday sermons. ${ }^{3}$ Each sermon continues about as long as a motion picture, and preachers have the time to include all aspects of popular story-telling, such as long narratives on exemplary, but also every-day figures; citations and allusions from Islamic texts or contemporary TV series; humorous incidents 
as well as political outrage. In short, participation in a waz mahfil promises salvation as well as fun and emotional upheaval.

This article describes an aspect of the performance and reception of the sermons that lies so close to their raison d'être that it is easily taken for granted: the contemporaneity of different languages within the sermon, and the manifold processes of translation and code-switching between these languages. The phenomenon of translation and codeswitching between languages forms an integral part of Islamic discourse in South Asia and worldwide. It increases in importance with the worldwide migration and the creation of multilingual communities. These build, however, on a vast variety of linguistic histories and configurations that defy any uniform concept of Islamic code-switching such as between a universalized Arabic and localized languages. In South Asia, codeswitching between languages is well-known from popular culture, most noticeably from poetry traditions and contemporary mass films, where reference to different linguistic formations is seen as emphasis as well as inclusion of associated communities. ${ }^{4}$ In Bangladesh, as I will briefly outline below, linguistic references are deeply entangled with language politics.

4 Methodologically, I focus on the message and its coding in performance rather than on empiric inquiry among recipients. However, these two poles are not oppositions. The performed texts themselves are, I argue with theories of aesthetic response and affective response, not separate from reception. The performances are the outcome of longstanding interactions of preachers and listeners and build on shared knowledge and expectations which enable joint, yet also individual, realizations of the performances. ${ }^{5}$ The preachers themselves learn much of their art by long-term listening experiences and are in constant interaction with listeners whose preferences are communicated to the preachers by organizers, co-travelers, or media agents. Furthermore, the performance itself includes concrete listener responses. Of course, more systematic empirical research on the discussions and perceptions of the participants would certainly be a valuable addition to the following observations that focus on the linguistic shifts in the performance. This nevertheless does not mean that audience research is the only way to access response.

5 I first clarify what I mean by codes and code-switching and make some introductory remarks on the linguistic history and presence informing the codes in the sermons. Secondly, on that basis, I turn to the performance of code-switching over the course of the sermons, first in the introduction and then in the main part. Thirdly, I reflect on poetic and rhetorical effects of this code-switching, to argue for the interdependence of argumentation and the aesthetic effect of the particular idiom of the waz mahfils. Before concluding, I fourthly venture into some aspects of the sonic dimension of code-switching as yet another crucial layer that influences code-switching in performance.

By this micro-example of contemporary public Islamic speech in one of the major Islamic languages I discuss the role of code-switching in configuring the relationship between religious and secular publics, in linguistic community formation and identity politics, and in the relationship between religious argumentation and poetic messages. More specifically, I argue that considering code-switching can shed new light on the argumentative role of Qur'anic quotations and their translation into Islamic practice. The Qur'an as the basis for argumentation is part of the multilingual relations and processes of translation, and therefore of the idiom relying on code-switching. From the perspective suggested here, the very productive role the Qur'an has for the sermons lies 
not only or maybe even not primarily on a deductive-argumentative level, but more in adding to an aesthetic effect of translation and code-switching. In turn, the analyzed code-switching becomes indispensable to religious discourse, and religious and poetic competencies overlap. Preacher and audience form a competent community of connoisseurs of code-switching in religious discourse.

\section{Code-switching and multilingual codes in Bangladesh}

\section{Multilingual code-switching}

7 Semiotics perceives culture as communication processes relying on the transmission of signs. This transmission works via codes, which must be "fully, or at least partly, common to the addresser and addressee, (or in other words, to the encoder and decoder of the message)" (Jakobson 1960:353). Each act of communication involves a multitude of codes; the communication in the sermons for example involves visual, auditory, spatial, as well as linguistic codes. This article, however, mainly focuses on the sermons' linguistic codes.

Analyzing these linguistic codes, insights from sociolinguistics are useful. Gumperz has defined code-switching "as the juxtaposition within the same speech exchange of passages of speech belonging to two different grammatical systems or subsystems" ( Gumperz 2002[1982]:59). Importantly, sociolinguistics investigates the reference ( indexicality ${ }^{6}$ ) of speech styles, such as bureaucratic jargon or a particular sociolect or dialect, to social situations or groups. This always includes a dialectical process: if a speech form is associated with a context of authority, it may come to be perceived as authoritative language. When a person then uses this language, he can project himself as an authority.

In this article, I only treat one of the multiple aspects of the linguistic codes employed in the sermons. While changes between dialectal forms of Bengali and the Bangladeshi standard Bengali are important, particularly in migrant communities, this article limits itself to what we might call multilinguistic codes: the inclusion of sentences or words from languages other than Bengali, in particular from Arabic, Persian and Urdu. There are two reasons for this focus. On the one hand, it is particularly relevant to the study of global Islam. Studies on Islamic sermons have described code-switching between variants of Arabic, emphasizing the importance of colloquial, i.e. spoken and regional, Arabic as indexing familiarity and informality as against formal Arabic. Patrick Gaffney, in his description of a sermon held in Egypt in 1978, notes a conflation of the preacher's roles with the switching to Egyptian dialect as against standard Arabic, or fușha: "Since Friday sermons are supposed to be delivered in the standard language, Shaykh Uthman is able to combine the august authority associated with the Quran and the classical tradition with the familiarity, concreteness, and creativity that are usually available only in the local patois" (Gaffney 1994:172). A valuable exception that concerns itself with other linguistic configurations has been Julian Millie's study (2012) on the indexicalities of Sundanese and the national standard language of Indonesia. Again, however, the main effect of codeswitching he describes is one that relies on the familiarity and relaxation opportunities of the local, colloquial of the two languages. Millie argues that the switches allow to bridge different orientations of preachers and listeners when it comes to expectations of sermons being transformative and contemporary or more ritualistic and gratifying in situ. 
10 My approach is somewhat different in that I have a look at a different set of languages with a very different historical trajectory; highlight the effects of code-switching for the interpretation of the sermons; and describe the role of the sermons' performance to not only activating, but building indexicalities. By this, I aim to interpret the effect of codeswitching beyond the transport of one particular indexicality into the sermon but rather highlight the structure of the code-switching itself.

11 A word of caution is necessary concerning markedness (the differentiation of one code from the other) and indexicality (the reference each code makes to a social group of sphere of discourse). Indexicality is open to change, historically as well as during every single performance. I will emphasize below the problems of ahistorical interpretations of stable indexicalities such as equaling Arabic to Islamic and the like. The same holds true even for markedness, which is not to be confused with etymology, but about language perception. An Arabic loan word, for example, might be perceived as Bengali, while another one might be perceived as Arabic: while the word "garib" is a very common word denoting "poor" and would go unmarked despite deriving from the Arabic gharib, another word of approximately the same meaning, "miskin", would be marked as Arabic. I furthermore trace the codes over the course of the performance. While they are more clearly separated in the beginning, the linguistic codes overlap increasingly.

While Bangladesh is the only South Asian nation-state whose identity is prominently based on language and is comparatively linguistically uniform, ${ }^{7}$ multilingual codeswitching is, as in other regions of South Asia, ${ }^{8}$ also important in contemporary Bangladesh. It might involve switching between different regional languages and the commonly understood Bangladeshi Bengali based on the Dhaka dialect taken up by the media, or that between languages, e.g. by Adivasi, Urdu and Rakhine communities. Two other varieties of code-switching important for our context are Bengali-English, which is most noticeable in urban middle and upper classes and structurally linked to employment in "Western" NGOs and a rising English medium education; and Bengali-Urdu/Arabic, which is related to the largely Urdu medium Islamic schools (madrasas) and labor migration to the Gulf countries. The diction of the sermons unsurprisingly mainly uses the second kind of code-switching' (with the density of Urdu in the sermons is the highest the mahfils held at madrasas). This already indicates how the employment of linguistic codes sets the sermons and their listeners in a particular social context.

\section{Indexicalities and markedness in the history of Bengali}

13 To fully understand the implications of codes, their markedness and indexicality, at least a short detour to history is inevitable..$^{10}$ Studies of Bengali up to the $19^{\text {th }}$ century point towards a long heritage of multilingualism that is similar to but distinct from phenomena in other Indian languages such as Malāyalam or Tamil. ${ }^{11}$ Qazi Abdul Mannan's 1966 study The Emergence of Dobhasi Literature in Bengal up to 1855, draws attention to a variant of literary Bengali which is characterized by a large number of loanwords from "PersioArabic" and "Hindustani." He indicates that this linguistic variety had originated as a literary language of Hindu authors and only "in the 18th century Muslim poets themselves had begun to adopt Dobhāṣi as their own peculiar language and that, therefore, as a literary diction, it was slowly being accepted as the preserve of Muslim writers" (Mannan 1966a:63). Mannan, also by his quotations-e.g. of Enamul Haq, who speaks of "two extremes of Bengali style: the one extreme being the 'Urduized' style of 
the Muslims, the other the 'Sanskritised' style of the pandits [sic]"-points towards a process in which language perception itself comes to the fore. He even unwillingly deconstructs the word "dobhāsis" itself, if we only read his comments about the origin of "Arabic, Persian and Hindustani" in Bengal from "Muslim culture" as his perception about them being Islamic (Mannan 1966a:158).

This common association is part of a historical process. Language, communal identity and the use of Arabic words have been linked to each other particularly since the second half of the $19^{\text {th }}$ century-the time that the Bengali waz mahfils came to the fore (Ahmed 1996 :100ff). "Authors of Islamic-Bengali works, writing as late as the 1870s, variously use the terms, "Islami Bangla" or "Hindi Bangla", to describe the language they used-the identification clearly being with both, language and the religion" (Ghosh 2006:266). This process has been interlinked with the cheap printing presses (battalā) bringing these idioms to the print market (Bhadra 2011). In short, already at the end of the $19^{\text {th }}$ century we see a close interaction between language, religious identity, and literary practice.

15 Aijaz Ahmad argues that many South Asian languages as we know them today were deeply influenced by religious reform movements. These reform movements "had the effect, first, of pressing the modern Indian languages into service for proselytizing, and, second, of greatly enhancing, at the same time, the prestige of scholarship in the classical language (Vedic and Sanskritic knowledges for Hindus, Arabic and Persian for Muslims) as the language of religious textuality" (Ahmad 1994:274.) The knowledge of Arabic became increasingly important and achievable for a Muslim public in South Asia. In the madrasa system of Deoband (and therefore many of Bangladesh's contemporary komi madrasas), proficiency of Arabic was not only an educational goal. As the schools relied (and continue to rely) on public subscription, and on persuading the public to give them funds, it also became important to communicate the competency in Arabic, as a sign of achievement, to the outside world of possible supporters. And while the role of Persian has declined since the $19^{\text {th }}$ century, Arabic seems to be on the rise, whether linked to Islamic education or the opportunities of the petro-dollar-economy.

When Jakobson states that a code must be "fully, or at least partially, common to the addresser and addressee" (Jakobson 1960:353), the nature of the partiality is left undecided. In the case of Arabic in Bengali sermons, however, this partiality seems to be decisive. One common view seems to be that Arabic is a liturgical language, which is little understood and of no semantic importance. ${ }^{12}$ I think that such a view has to be partially corrected and made more specific. It does not do justice to the audience's competences, particularly the phonetic ones. Many, if not most, of the listeners have studied in a maktab, a pre-primary Qur'anic school, where they memorized parts of the Qur'ān and acquired reading skills, which means that they are capable of differentiating and recognizing Arabic phonemes. Another important location for acquiring competency in Arabic is Islamic ritual: most of the listeners of waz mahfils are familiar with the Arabic parts of the obligatory prayer, nearly all of them with many parts of the Arabic Friday sermons, and everybody with the call to prayer. And there are, among the listeners, people with either experiences or aspirations of travelling to the Middle East, as well as graduates and students of Islamic schools.

17 Arabic quotations do not simply index divine language and divine sound-which they certainly, and importantly, also $\mathrm{do}^{13}-$, and remain otherwise undifferentiated. Rather, they seem to form a complex mix of recognition with different degrees of familiarity. My experiences with the different people who helped me write down the audio-recordings 
from my fieldwork support this point. Some Arabic parts were written down in Bengali script with a stunning precision, while others were simply omitted or misheard. All this implies that the receptive relation to this code is one of recognition, filling in and acquiring competencies, rather than passivity.

The sermons themselves take part in and extend these active learning processes. These are not only a matter of didactic communication-the preacher as teacher to the audience as learners-but are interlinked to the audience members communicating their success among each other as well as the audience in the tent communicating to those outside of the tent. As mentioned, this communication of learning successes is important for the working of institutions of Islamic learning. At a mahfil held at the inception of a newly founded (but not yet built) madrasa, for example, the preacher recites Arabic sayings of the Prophet to an audience of enrolled and prospective students. Both the preacher's role as a teacher and the children's success in repeating the Arabic words are communicated to the boys' school's surrounding area, as also their voices are included in the transmission by loudspeakers. Importantly, the preacher furthered the learning success of the audience members by repeating set phrases with set speech melodies, to be memorized more easily. ${ }^{14}$

19 This initial discussion of the Arabic code of course has to be complicated by the fact that in Bangladesh the perception of Arabic is always tied to that of Urdu. And Urdu has, with the Pakistani insistence on it being the sole language also in East Pakistan and the language movement for Bengali as the seed of the national movement, undergone extreme upheavals in the twentieth century. From a nationalist point of view, there is no Urdu in Bangladesh besides that of the "stranded Pakistanis" and other "pro-Pakistani", i.e. "anti-Bangladeshi" quarters, such as the Urdu-medium komi madrasas. This perception partly creates and partly correlates to the larger situatedness of waz mahfils as a cultural practice of, if not opposition, so at least not full subscription to the Bengali secular frame that would easily brand its linguistic outlook as non-Bengali. I have a different perspective. I do not interpret the waz mahfils' linguistic practice as part of a uniform project of Islamization, but rather see it as part of the aspects of Bangladesh that are suppressed in modernist-nationalist imaginations. In this regard, it is insightful that a literary historian remarks that "[w]ith the standardisation of the Bengali language, Dobhāshī lost its relevance and nearly disappeared as a productive literary idiom during the first decades of the twentieth century" (d'Hubert 2014). However, while the term dobhasși is not anymore in use, the idiom of the waz mahfils shows that in the oral sphere, the phenomenon continues to be immensely productive. ${ }^{15}$

The code-switching I describe is linked to, but distinct from, efforts to explicitly reinterpret the indexicalities and markedness of languages as part of shaping the configuration of linguistic identities. A case in point is the discussion around the proper farewell-formula. The discussion on replacing khodā hăfez by allāh hāfez is a pan-SouthAsian one with many local shades and dynamics. In Bangladesh, a famous preacher and MP of the largest Islamic party, the Bangladesh Jamaat-e-Islami (BJI), tries to set himself up as the avant-garde of this discussion. He explicitly argues for charging the every-day interaction of the farewell-formula with a particular indexicality that is aligned to his party or at least ideology. In a similar vein, he advises to replace another farewellformula: "The boy, the small child is going to school. The mother sees him off. She says to the child "țā țā [bye]", the boy says "Bye bye [sic], yāi yāi [I go / echo-construction], I might not come back." Say: "no, I seek refuge with Allah! [nā a ù dhu bi-llāh]" ${ }^{16}$ Instead, the 
preacher suggests to use the Arabic phrase "in the trust of Allah" ( $f_{i}$ 'amāni lläh) instead of "tạ tạ" and "bye bye". He thereby creates a binary juxtaposition between Arabic and English. Building on the naturalized association of Arabic with Islam and speaking as a preacher with a seemingly universal message, he activates an opposition between Islam and West, and therefore charges his opponents with the accusation of being Westernized and anti-Islamic. The decision to which side of the binary the audience belongs therefore becomes anchored in their every-day life- by the newly introduced indexicality of changed every-day expressions.

However, this explicit instruction to change indexicalities should not be confused with the general diction of code-switching in waz mahfils. Actually, the effort and explicitness of the effort to change indexicalities towards exclusivist nationalism shows that it is something that requires extra work rather than being "naturally" embedded in the performance expectations. The instances of code-switching which I analyze below are, to the contrary, not explicit, but rather rendered opaque. The multilingual codes are in most cases applied rather than shaped explicitly. Furthermore, it is interesting to notice that the above explicit reorientations of codes are concerned with every-day practices. When in the following considering the multilingual codes in the different parts of the sermons, my focus is on their effects for the overall argumentation and ways of interpreting and performing the Qur'ān.

\section{Multilingual code-switching in the performance of waz mahfils}

\section{Interweaving linguistic codes in waz mahfils}

In the following, I present some examples from sermons that I transcribed and analysed, partly from my own recordings, and partly from commercial ones on sale or available on Youtube. The examples are selected to illustrate phenomena that I observed across a wide variety of sermons. I will present the examples roughly according to their occurrence over the course of the sermon as I think that this temporality matters a lot for the reception process.

When the sermon begins, the recipients have already been attuned by the spatial setup of the sermon space that the tent separates from the surroundings, as well as by the visual and vocal announcements of the speakers and the local notables by the event's organizers. The beginning of the sermon, however, is the beginning of the preacher's own introduction of what is to come, and marks the specific "contract" between those present in the tent and the mutual declaration about which kind of speech act they are going to take part in. ${ }^{17}$ For the argument presented here, this is crucial as it is a re-actualization of the "markedness" of codes that will provide the basis for the remaining sermon.

The introduction employs the different linguistic codes for different functions and directions of communication. Arabic clearly dominates in the beginning, in which the preacher recites the parts termed metonymically "khutba", since they are shared with the Friday sermon which is also called by the same name. Fittingly, the preacher at that time is typically withdrawn, as if he himself were not present, but rather figured as a medium for the divine word. 
While also the next section of the introduction remains predominantly Arabic, audience participation increases: while before, it was the preacher speaking for the gathering, the following greeting and blessing the Prophet is performed jointly by preacher and audience. The Arabic part of the introduction shifts, from the preacher reporting a distant message, towards the audience directly communicating with Muhammad as an intercessor close to them. Both aspects rely on linguistic and performative competency in the Arabic code, on part of the audience as well as the preacher. If Arabic had been indexing ritual and divine sphere before, the code-competent listeners now participate in this sphere.

In the following part of the sermons' introduction, the proportion of Arabic and Bengali shifts towards the latter, and so does the communicative direction associated with the respective language. The greeting "as-salāmu 'alaikum wa rahmmatu llāhi wa barakātuhu", for example, had already stood at the inception of the sermon. At this later point of the introduction, it is a repetition. It is, however, now directed to the audience, which in turn responds energetically (which it had not done at the first instance). After preacher and audience confirm their co-presence, the preacher addresses the audience with a formal Bengali address, which is shared across different kinds of public speech.

The categories of his address, however, are partly specific to religious speech, as they are interlaced with Arabic and Urdu, a mix which again has specific rhetorical effects. The Bengali address includes socially relevant hierarchical praise, thanking the chairman ( sabhāpati) and special guest (biśeș atithi) by name, thereby repeating information already familiar to many from the posters announcing the mahfil. Apart from the notables, the general audience is addressed along general social groups such as "the honoured ulama [ U, 'ulamā-ye kerām]", "teachers of madrasas [mädrāsār śikșak]", "journalists [sāṃbādikbrnnda ]"; "honoured inhabitants of the area [sammānita elākäbäsi]"; and most importantly to the "mothers and sisters behind the veil [pardāy àrăle mā o bonerā]" and the audience members as "my brothers [ämär bhäirā]" or "Brothers of Islam [P/U, braderān-e Isläm]" or as "honoured attendees [U, muhtaram häzirin]. These group addresses in second person plural differ from those in second person singular, characteristic of the personalized conversation described among Egyptian sermons in mosques as well as on TV-preaching. ${ }^{18}$ They communicate and create a social imaginary by taking, on the one hand, elements from the social world, and on the other proclaiming this perspective as a general reality, at least of the audience. Hence, the address also varies with the respective preacher's vision of society, ${ }^{19}$ as different preachers want to promote different ideals to which the audience as subjects must respond. They therefore employ the double bind criticized by postcolonial studies under the rubric of interpellation: once people react to a name and category they are called by, they admit to that category's classificatory regime (Ashcroft, Griffiths and Tiffin 2009:203).

What matters in our context is that the social imaginary often relies on Arabic and Urdu terms as markers of specifically Islamic aspects of the identity, particularly in set epithetname complexes such as "honored scholars" [muhtaram 'ulamā-ye kerām] as opposed to the Bengali "honored inhabitants" [sammānita eläkäbäsi]. The fact that each address is marked as one language is exemplified by the circumstance that they do not combine to something like muhtaram eläkäbäsi. In short, while Arabic indexes ritual, Urdu is added to Bengali to relate to an Islamic social vision, which is institutionally located first and foremost in the Urdu idiom of the madrasas. 
last part of the introduction builds on the initial Arabic ritual phrases uttered by the preacher, but now integrates them into Bengali sentences. This technique locates the eternal and delocalized ritual utterances of submission, praise, and seeking of refuge ( basmala, hamd, isti adha) in the sermon gathering. At this point of the introduction, therefore, it is possible to closely interweave the different indexicalities established before: Arabic as index of ritual, Bengali as index of the social here and now. ${ }^{20}$

\section{Code-switching in the main part of waz mahfils}

30 The main part of the sermons overwhelmingly consists of Bengali. Nevertheless, as in dobhāṣi, we find many instances of the inclusion of Arabic and Urdu words and expressions, ranging from single words to longer citations from Qur'ān and Hadit. It is the contention here that these different scales build onto each other, and that the reception and construction of larger units to a great deal relies on the micro-level dynamics which constitute a poetic effect of their own. I will exemplify these dynamics referring to three different quotations from three different preachers at three different occasions, all of which are united by including a Qur'annic quotation, which triggers further multilingual code-switching. While I translated the quotations into English, I noted, very approximately, the respective linguistic code of the original where it would not be perceived as "normal" Bengali. I did so by acronyms and different font colors ( $\mathrm{Urdu}=\mathrm{U}$, Arabic $=\mathrm{A}$, English $=\mathrm{E}$, Persian $=\mathrm{P}$ ). The underlining does not need to concern us here, as it indicates a performative aspect that I will describe further down.

Let us start our reflections by looking at the elaboration on a phrase which is part of every sermon, be it held in mosques on Friday or at a waz mahfil, and which therefore clearly builds on prior knowledge of the listeners: "Oh our Lord! We have wronged ourselves. (Q7:23a)." The preacher, in a tent built up by on the street close to one of Dhaka's indoor-markets, whose shop-keepers had organized the mahfil, does not simply repeat the ritual formula, but extends it:

Riches and goods [dhan-sampad], sense and perception [jñān-buddhi], honour and prestige [man-(U)'izzat]: you raised us with everything that is necessary, oh you guarding [pälnewälā] God [khodā]! [...] (A, Q7:23b) We have wronged ourselves [ zalamnā anfusanā ]. Oh God [khodā ${ }_{2}^{21}$ we live on your earth, from your light and wind. With the hands you gave us we defy [(P) näfarmäni] you; with the eyes you gave us we defy you, with the power of the sense and perception [jñan-buddhi], the honor and prestige [mān-(U)'izzat] which you gave us we defy you-therefore we became great sinners, delinquents, transgressors [(B) bara (P/U) gunāhgār, (B) pāpì, (A/U) zālim]. (Chāleh 2013:3mins54)

The elaboration of Allah's favor as well as the supplicant's wrongs-and thus the extended translation of the $\bar{a} y \bar{a}$-are structured along three pairs of synonyms: "Riches and goods [ dhan-sampad], intelligence and knowledge [jñāna-buddhi], honour [män-(U) 'izzat]." Apart from rare instances of multilingual creations of single words, ${ }^{22}$ these pairs are the smallest units of code-switching within the sermons. While one of their rhetorical effects certainly is emphasis-the effect of every kind of repetition, and one more elegantly done here by not repeating exactly the same word ${ }^{23}$ our focus on multilingual code-switching shows that their effects are by no means limited to mere emphasis, but also entail seeds of multilingual language play. How do they do so?

Echo-words and word-parings, mechanisms of asyndetical adjacency of words, are typical for and ubiquitous in South Asian languages. From the point of view of multilingual code-

South Asia Multidisciplinary Academic Journal , Free-Standing Articles 
switching considered here, it seems important to notice that while linguistic surveys of South Asian languages have described these phenomena, they have neither considered multilingual relations nor wider rhetorical effects. Often, other dimensions of echo-words and other "pairings and doublings" are highlighted. Focus has been laid on the semantic distance of the combined words, leading to categorizations such as "synonyms and nearsynonyms" on the one, and "accumulative meaning" created by "[t]wo meaningful lexical items" on the other end of the continuum (Thompson 2010:664). I connect to the echowords' semantic effect of de-centering a notion (Montaut 2008:38), or in Rabindranath Tagore's expression "signifying 'etc.' and 'indeterminacy' [anirdista-prabhrti-bācak]" ( Thākur 1367[1960]). This de-centering, commonly used particularly in spoken Bengali, has its own rhetorical effects (decentering a name is insulting) and can, if two terms are combined, be employed for re-centering a notion. This re-centering relies on the fact that synonyms are never identical. If one word is paired with a synonym, a subtle difference is introduced which serves as the basis for shifting meanings.

I argue that such possibilities for semantic shifts increase when the synonyms stem from different languages, as in this case what we might call "synonymization" involves (and conceals) a translation. The synonymization of "(U/P) gunāhgār, (Bengali) pāpi, (U) zālim" for "sinner" at the end of the above quotation shows the wide range of combined terms. For example, zālim (literally oppressor), is surprisingly included among those asking for mercy. Its inclusion, however, takes up the Arabic "zalamnā" in another morpheme, and thereby establishes yet another tie to the Qur' annic quotation.

This brings us back to the dimension of indexicality. With multilingual relations being marked and indexed in the specific ways described above, we must complement the inquiry about the semantic shifts of synonymization with the inquiry about the axis of multilingual relations. Among the three pairs of synonyms introduced in the above quotation, mān-'izzat not only involves a re-centering of the notion of mān along the semantics of 'izzat (and vice versa), but also achieves a merging of two linguistic codes and their indexicalities; and the accumulation of words for sinner is not only an emphasis of sinner by including the different semantics of $(U / P)$ gunāhgār, (B) pāpi, (U) zālim, but also achieves an accumulation of the different linguistic spheres (Bengali, Persian, Arabic) and a synonymization of their different indexicalities. The waz mahfils create relations not only of levels of semantics, but also of the spheres of discourse linked to the indexicalities of the linguistic codes employed.

Let us have a look at another case in which a preacher, this time in a village in Bangladesh's South-East, recites and translates and explains another āyā (Q51:56). As I had just met him minutes before the performance, his flexible way of including me in the sermon stresses the importance of the "composition in performance" typical of oral poetry (Lord 1960):

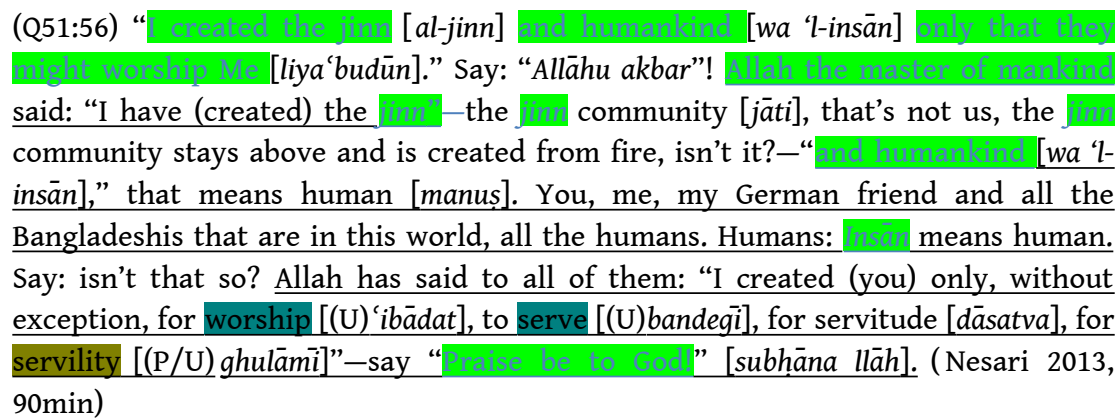



mark its all-encompassing nature. After establishing the universal nature of his address, the remainder of what the preacher emphasizes as direct speech of Allah is a translation of liya 'budūn by the synonym-chain "ibādat, bandagi, dāsatwa, ghulāmi". These synonyms again emphasize Allah's command by repetition. Again, they are aligned to the Qur' anic text by taking up the root ya'budūn before in 'ibädat, and at the same time widen its semantics. They re-center the notion of "worship" into the direction of "submission/ servitude". This of course is not a one-way process: as above with the term papipi, here dāsatva is also a Sanskrit term of Vaișnava theology ${ }^{24}$ which is here aligned with Allah's order. following Saussure's linguistic analysis, distinguishes between syntagmatic and paradigmatic structures. The former are the combination of signs in the chain of speech, opposed to "what precedes and what follows", while the latter is about the associations and substitutions of each unit (Barthes 1986 [1964]:58ff). shift the attention away from the syntagmatic and towards the paradigmatic. By spelling out multilingual near-synonyms one after the other, the paradigmatic gets spread out into the syntagmatic dimension. In this way, it starts to stand in competition with other syntagmatic procedures, most importantly argumentation. The paradigmatic relation between synonyms becomes also evident where multilingual synonyms are not adjacent to each other as in the pairings or longer chains discussed so far, but are scattered over the course of several sentences. In these cases, the synonyms might take the same syntactical position in stock sentences, creating equivalences and substitutions on the paradigmatic plane. One very common case is the synonymization between abatirna and näzil for "sending down" the Qur'ān. Both synonyms might follow one another, or two identical sentences might be repeated one after the other, only substituting näzil with abatirna, or vice versa. As in the other cases of synonymization, this choice influences the semantics of both terms, which have a long history of interaction.

the rhetorical effects of this structure by turning to a third example, which is taken from a recording of the yearly mass gathering of the abovementioned political preacher associated with the BJI. As in the last example, also here the preacher takes up the notion of ' $-b-d$ as denoting servitude, ${ }^{25}$ but this time as a description not of humans, but other deities:

(Q7:194a) "Lo! Those on whom ye call [tad'üna] beside Allah are slaves ['ibädun] like

you." The Quran taught the believer and servant: Those besides Allah to whom you take refuge [āśraj grahan karo ], whom you invoke [dāko], whose help you want [ sāhäyya cāo], they are like you, my servants [(U) banda] and my slaves [(U/B) ghuläm ]. Hence what creates in you respect [ maryādā], self-respect [ätmamaryāàa $]$, personality [(E), sic], individuality [(U), shakhsìyat $]-$ is (your) belief [(A), imān]. ( Sayeedi n.d.:4min15)

41 Next to the translation of 'ibād by the two synonyms banda and ghulām, we find a rendering of the Qur'ānic tad' unna into three Bengali expressions. The preacher follows the option of re-centering the semantics of $\operatorname{tad}$ ' $\bar{u} \overline{\bar{a}}$ and builds up a tripartite structure, while not including different linguistic indexicalities. These, however, follow in the following sentence: "Hence what creates in you respect [maryādā], self-respect [ àtmamaryādā], personality [(E), sic], individuality [(U), shakhșiyat]-is (your) belief [(A),

South Asia Multidisciplinary Academic Journal , Free-Standing Articles 
imān]" (Sayeedi n.d.:4min15). Here, the different indexicalities play major roles, and the synonymization binds together quite different terms. The indexicalities point to the "modern" by a technical term of the discourse of collective psyche and identity ( $\bar{a}$ tmamary $\bar{a} d \bar{a}$ ); to English and English education so closely tied to wealth by personality, while at the same time ennobling the row with the Urdu indexicality of shakhsigyat, which distinguishes it from any "Westernized" community.

The two tripartite chains of synonymic expression relate to one another. The tripartite structure is a common feature of Bengali folk narration and connects the different tripartite synonymizations to each other. This structural parallel between "ātmamaryādā, personality, shakhsiyat" and "whose protection you accept [ä́ray grahan karo ], whom you call [d̄āko], whose help you want [sāhāyya cāo]" links the Qur'ānic translation to a part of the argumentation which is otherwise not connected to the Qur'anic statement. In this way, the preacher's vision of monotheism as the basis for indomitable personality can be "deduced" from the Qur'an. The argumentative leap does not jump to mind as the synonymization and its structure catches the attention.

\section{Argumentation and aesthetics of code-switching}

The synonyms each time encapsulate, in an extremely condensed manner, the processes of learning and applying what has been learnt, of recognizing and applying nets of equivalences. This is a process of participation of the listeners, and a joyous one, as it is a learning process which often includes new combinations but also, as we have learned with the ritual formulas, the well-known. It is a poetic pleasure, as it relies on the approximate, and phono-centric, and, as it is related to echo-words, every-day word games. Here lies a particular pleasure of listener participation which is facilitated by the loosening of terms, the new or well-known combination of them with new terms from the other code: a competence involving poetic operations of language play. This play emphasizes form, more specifically: multilingual form of substitution and accumulation of alternatives. The recipient is continuously engaged in creating the code (Iser 2006:64), without being able to apply any pre-given code found elsewhere: in this way, the codeswitching itself becomes the code of the sermons as a literary device.

While code-switching is a term from sociolinguistics, the perspective here focuses on its literary effects. Unlike sociolinguistics, which concentrates on conversational, every-day code-switching, we discuss a specific convention of code-mixing in a context of oral poetics. Turning again to Bengali literary history, it is noteworthy that Thibaut d'Hubert argues that the $17^{\text {th }}$ century Arakanese/Bengali poet Âlāol displays "a conscious will to literarize vernacular poetry while retaining its association with music and performance, the promotion of multilingual literacy in multipolar social gatherings" (d'Hubert 2014). ${ }^{26}$ And Abdul Mannan in passing also highlights that the "poetic quality" of dobhassi had been noticed by contemporaries (Mannan 1966b:61). ${ }^{27}$ It is this poetic effect of code-switching in performance which lies at the basis of the phenomenon described in this chapter. Importantly, again, this effect is not created by the mere fact of different codes, but by their combination in performance, or, from the perspective of the recipients, over the course of reception.

Code-switching integrates and relates to other translation processes which we encounter in the waz mahfils. The translation encapsulated in the synonymization is not equal to the 
argumentation of the preachers. However, the pleasure it develops stands in relation to the argumentation which preachers claim to derive directly from the Qur' ann. I here want to connect to a thought of the literary scholar and semiotician Roland Barthes. Barthes makes an important point about the enthymeme, the famous rhetorical syllogism that is characterized by merely probable premises or by not fully mentioning its premises. ${ }^{28}$ Instead of taking this as an argumentative deficiency, Barthes parades the enthymeme's pleasure. Its strength, he claims, lies in "giving the listener the feeling that he has brought it [the argumentation] to an end himself, by his own mental power: the enthymeme is not a syllogism truncated by defect or corruption, but because the listener must be granted the pleasure of contributing to the construction of the argument; it is something like the pleasure of completing a given pattern or grid (cryptograms, crossword puzzles)" (Barthes 1994:60). I want to suggest that the performed interpretation of the Qur'an which relies on the multilingual code-switching and the fuzziness and word-play of near-synonym-pairs similarly leads to the listeners traversing an active and pleasurable journey through the sermon. The community of listeners to waz mahfils is in this respect one built on appreciating and being competent in multilingual substitutions. Listening to sermons at the same time builds on this appreciation and competency and expands it: the listeners have the chance to become competent codeswitching connoisseurs.

\section{Sonic Translation}

Let me, before concluding, venture beyond the multilingual code-switching discussed so far and consider the vocal performance of preachers and its relations to the multilingual code of the sermons. In the waz mahfils, there is a strong association of each of the multilingual codes with one particular vocal style. While all of them might just be spoken in a normal voice, most preachers employ one style of reciting the Qur'àn, one style of reciting quotations from Urdu poems (another case of multilingualism that we have not had the space to include here), and one style of chanting Bengali passages. The change between these performative styles can of course not meet the pace of the multilingual code-switching described above: we can say that the musical codes, particularly the Bengali chanting which I marked by underlining in the quotations, cut across several of the multilingual codes we have analyzed so far.

The chanting of Bengali passages is of overarching importance to the waz mahfils, as it identifies individual preachers as well as the genre of waz mahfils. It shares characteristics with several other musical codes, most importantly for our context, with both Bengali story-telling traditions (pũthi pāth), ${ }^{29}$ and Qur' ānic recitation. The most common melody seems to be taken from the final cadence of a "classic" Egyptian Qur'an reciter. ${ }^{30}$ The melodies that preachers employ when chanting passages of their sermons relate to the transcultural creation of an Islamic soundsphere ${ }^{31}$ through the dissemination of mechanically reproduced media ${ }^{32}$ and at the same time connect to characteristics of traditional Bengali narration. Preachers also link the Bengali chanting to the Qur'an by reproducing gestures typical for Qur'anic recitation when chanting and by doing so particularly often when translating Qur'ānic verses.

While the sermons' main part differs from the introduction in that it closely interweaves the multilingual codes using a high frequency of code-switching and synonymization of terms from different linguistic codes, the musical code goes one step further: it indexes 
several other codes at one time, a step not possible on the linguistic level, as this would be akin to create a new language.

This musical layer has repercussions on the relation between the Qur' anic text and the preacher's interpretation. As the melody binds together the Qur'an and its translation, it might serve to set the Qur'ān apart from the preacher's commentary, drawing a line between translation and interpretation. In the third example, the chanting ends after the translation of the Qur' anic verse, just before the preacher links it to his interpretation, which is marked by "that's why [sutaräm]". On the other hand, the same quote also shows how the tripartite translation of tad'una is vocally linked to the Qur'ànic text, naturalizing the translation as equivalent to the Qur'anic text. If the translation in this sense becomes the Qur'ān, the following row of synonyms (maryādā, àtmamaryādā, personality, shakhsisyat) becomes akin to the translation, despite not being anchored in the quoted passage.

The second example cited above combines yet other possibilities for demarcation and inclusion. The preacher's explanatory comment about the jinn is not chanted at all, but only the translation is, thereby setting the Qur'anic translation off from the preacher's comment; on the other hand, the translation also includes the chain of synonyms " ibādat, bandegì, dāsatva, ghulämi". It is also interesting to note that in this case, wa "l-insän is first chanted in slow Qur'anic recitation, but is then picked up in the melody of Bengali chanting.

So far, the Bengali chanting seems to serve a metalingual function of indicating which part of the preacher's speech is endowed with the authority of being a Qur'anic quotation, that is, the speech of Allah. However, the employment and significance of the chanted passages is, as has been mentioned, also greatly influenced by Bengali storytelling techniques. It is part of a narrative design highlighting dramatic scenes to evoke particular emotional experiences (Stille 2016). This has two important implications for the ways in which Arabic quotations are integrated in the sermons.

The first is that within the dramatic and chanted scenes, the rules of re-citation are primarily oriented towards the emotional effect of the scene, and not towards the citation's origin. This means that a lot of space is given to elaboration of the scenes in an imaginative, "subjunctive" mode, often geared towards emotional identification of the audience with the heroes of the story. Integrating well-known Arabic phrases into the narration of a sermon can open up further possibilities in this process. The audience, for example, is habituated to recite along with the preacher when he cites the profession of faith. This participation opens up possibilities for a particular narrative design. Let us shortly consider one example from a sermon of a very young preacher, who very obviously follows routine techniques of waz mahfils. The quote is from the climax of the story of Abū Jāhl's son 'Ikrimah and is of course chanted:

After 'Ikrimah saw the sweet words of Allah's Prophet, after he saw the sweet smile of Allah's Prophet, he slowly approaches the Messenger and says: "Dear Prophet, oh Prophet, please be so kind [ $(U / B)$ meherbäni kare] to make me read the profession of faith [kālemā] and make me Muslim." The Prophet says: "recite [paro]: '(A) There is no god but Allah and Muhammad is His Messenger!'” (Siddiq 2012, 28min54)

53 This quotation shows the importance of direct speech and innerdiegetical address to the Prophet by repeated vocatives. It also shows the allegiance between vocal style and linguistic code, as the preacher switches to the typical melody of reciting the profession of faith, rather than continuing the melody of the Bengali chanting he had adopted for 
the passage up to that point. Importantly, the citation simultaneously operates on two levels: on that of the narrative and that of the communicative situation in the tent. Thereby, a doubling of roles is achieved. The preacher as Muhammad advises the convert in the story, and the preacher as preacher advises the audience to recite the profession of faith. Reciting along, the audience in turn recites the profession of faith simultaneously as audience in the here and now and as the character of the story with whom it identifies.

The particular narrative design of the sermons, secondly, also explains other characteristics of Qur' annic re-citations in the sermons. The technique of making Qur'anic quotations part of longer narratives has a long history in Islamic popular literature,$^{33}$ but the Bengali chanting casts a particular edge to it: as it is linked to the speech of Allah by its linkage to the Qur' an on the one hand and to dramatic passages in Bengali narrative history, it is not just any inclusion of the Qur'an, but one which teases out the Qur'an's dramatic, dialogical, sides. The quotations above show that Arabic quotations and their Bengali equivalent-equivalent as interweaving linguistic and musical indexicalitiesalways feature dialogue: between participants of the Heilsgeschichte as well as between believer and Allah. In other words, while the Bengali translation is made to resemble the Qur'anic diction, this diction is interpreted and rhetorically transmitted to the audience as a dramatic script of intimate communication. The audience of the waz mahfils participates in a kerygmatic process.

\section{Evidence and Pleasure}

Code-switching is a universal phenomenon of community formation. Religious speech switches between sacred and profane languages, and this particular code-switching becomes crucial in extending the religious to the public sphere. The pleasure of including different codes and languages is a characteristic of poetic messages and part of South Asian popular culture. ${ }^{34}$ Against this background, the specificities of the code-switching considered in this article add to our general understanding of code-switching in Islamic sermons. The multilingual configuration considered here adds to existing studies which focus on the switches between dialect and standard forms, thereby deepening our understanding of Islamic preaching outside the Arab world.

Code-switching in waz mahfils often occurs at a very high speed on the level of directly adjacent synonyms, but has effects on the sermons at large. The paradigmatic density created by the parallel inclusion of different linguistic codes pushes the preachers and listeners to think along paradigmatic substitutions of synonymous meanings but different indexicalities. This, I argue, de-emphasizes the syntagmatic line of thought and argumentation, and allows listeners to connect to their associative field of multilingual substitutions. The substitution process, which becomes the primary focus, creates a poetic effect of its own, as it constantly de-centers individual notions in favor of multilinguistic play. The pleasure created by this process might be the oral/aural and performative equivalent to the aesthetic effect of a simultaneity of different scripts-and indeed, written representations of the sermons' idiom try to match linguistic codes with styles of writing. ${ }^{35}$

From the perspective of code-switching in performance, also formal translation mechanisms in the sermons-the most prominent of which is the translation of the Qur'an-can be evaluated anew. As opposed to a point of view that argumentation and 
persuasion are derived from the Qur'an as a scripture of law, the inclusion of Qur'annic quotations into dynamics of multilingual code-switching and its aesthetic effects emphasizes a poetic form of evidence. This form of evidence emphasizes the dramatic and dialogical structure of the Qur'an, often in dramatic scenes. The preachers mark these by chanting, thereby adding yet another binder to the already interwoven linguistic layers. The sermons thereby cater to recipients who appreciate this particular blending, and preachers have to be competent in achieving it.

As mentioned in the introduction to linguistic codes in contemporary Bangladesh, political Islamic projects try to appropriate code-switching competence as a tool for exclusive community formation. However, from this does not follow that the codeswitching of the waz mahfils is necessarily one of communalism. My argument rather stressed its particular possibilities for play and pleasure. I hope that communalist projects will not be successful in occupying all connoisseurs of this practice. I furthermore think that scholarly as well as politically, recognition rather than negligence or, worse, denial, of the connoisseurship developed by waz mahfils is the way to go.

\section{BIBLIOGRAPHY}

Ahmad, Aijaz. 1994. In Theory: Classes, Nations, Literatures. Delhi: Oxford University Press.

Ahmed, Rafiuddin. 1996. The Bengal Muslims, 1871-1906: A Quest for Identity. Delhi, New York: Oxford University Press.

al Siddikỉ, Kafiluddin Maulabỉ Sāheb. n.d. Majmuye Oȳāj Nāmā bā Nachihate Hedāyet. Kalikātā: Gaosiȳā Lāibrerì.

Ashcroft, Bill, Gareth Griffiths, and Helen Tiffin. 2009. Post-Colonial Studies: The Key Concepts. London: Routledge.

Bakhtiȳārì, Ājhār A. 2003 [1927]. Majmuye oyāj śariph o hedāyeter saral path. Kalkātā: Gaosiȳā Lāibrerì.

Barthes, Roland. 1994. “The Old Rhetoric. An aide mémoire.” Pp. 11-93, in The Semiotic Challenge, edited by R. Barthes. Berkeley: University of California Press.

Bassiouney, Reem. 2013. "The Social Motivation of Code-Switching in Mosque Sermons in Egypt." International Journal of the Sociology of Language 2013(220).

Bhadra, Gautama. 2011. Nyārāā Bațtalāỳ yāỷa ka'bār? Kalkātā: Chātima Buks; Paribeśak, Presiḍensī Lāibrerī.

Chāleh, Ābu J. 2013. Wa'z mahfil. Recording 11.01.2013.

d'Hubert, Thibaut. 2014. "Dobhāshī.", in Encyclopaedia of Islam, THREE, edited by K. Fleet, G.

Krämer, D. Matringe, J. Nawas, and E. Rowson.

Fish, Stanley. 1970. "Literature in the Reader. Affective Stylistics." New Literary History 2(1):123-

62. 
Gade, Anna M. 2004. Perfection Makes Practice: Learning, Emotion, and the Recited Qur'ān in Indonesia. Honolulu: University of Hawai'i Press.

Gaffney, Patrick D. 1994. The Prophet's Pulpit: Islamic Preaching in Contemporary Egypt. Berkeley, Calif.: Univ. of California Press.

Ghosh, Anindita. 2006. Power in Print: Popular Publishing and the Politics of Language and Culture in a Colonial Society, 1778-1905. New Delhi: Oxford University Press.

Gumperz, John J. 2002 [1982]. Discourse Strategies. Vol. 1. Cambridge: Cambridge Univ. Press.

Hansen, Kathryn. 2016. "Passionate Refrains. The Theatricality of Urdu on the Parsi Stage." South Asian History and Culture 7(3):221-38.

Harder, Hans. 2016a. "Die südasiatischen Neusprachen im vielsprachigen Kontext des indischen Subkontinents. Ein historischer Abriss.” ZWG (Zeitschrift für Weltgeschichte) 17(1):33-49.

Harder, Hans. 2016b. "Einleitende Paratexte in südasiatischen Neusprachen. Eine Erkundung." Zeitschrift der Deutschen Morgenländischen Gesellschaft 166(1):153-80.

Iser, Wolfgang. 1978. The Act of Reading: A Theory of Aesthetic Response. London and Henley: Routledge and Kegan Paul.

Iser, Wolfgang. 2006. How to do Theory. Malden, MA: Blackwell.

Jakobson, Roman. 1960. “Closing Statement. Linguistics and Poetics.” Pp. 350-77, in Style in Language, edited by T. A. Sebeok. Cambridge, Mass.: Wiley.

Jalil, Muhammad A. 1999. Śāh Garibullāh o jañganāmā. Ḍhākā: Bāṃlā Ekāḍemī.

Kane, David M. 2008. "Puthi-Pora. 'Melodic Reading' and its Use in the Islamisation of Bengal." Ph.D., School of Oriental and African Studies. London.

Karassery, M. N. 1995. “Arabic-Malayalam.” Pp. 168-73, in Kerala Muslims. A Historical Perspective, edited by A. A. Engineer. Delhi: Ajanta.

Kṛș̣̣adāsa Kavirāja Gosvāmi, Edward C. Dimock, and Tony K. Stewart. 1999. Caitanya caritāmrta of Kṛșnadāsa Kavirāja: A translation and commentary. v. 56. Cambridge, Mass.: Dept. of Sanskrit and Indian Studies, Harvard University; Distributed by Harvard University Press.

Lord, Albert B. 1960. The Singer of Tales. Vol. 24. Cambridge, Mass.: Harvard University Press.

Mannan, Qazi A. 1966. The Emergence Of Dobhasi Literature in Bengal (upto 1855). Dacca: Bangla Academy.

Millie, Julian. 2012. "The Languages of Preaching. Code Selection in Sundanese Islamic Oratory, West Java.” The Australian Journal of Anthropology 23(3):379-97.

Montaut, Annie. 2008. "Reduplication and 'echo words' in Hindi/Urdu." Pp. 21-61 in Annual review of South Asian languages and linguistics, vol. 2008, ARSALL // Annual review of South Asian languages and linguistics, edited by R. Singh. Berlin: Mouton De Gruyter.

Muneer, Aram K. 2015. "Poetics of Piety. Genre, Self-Fashioning, and the Mappila Lifescape." Journal of the Royal Asiatic Society:1-19.

Nagel, Tilman. 1967. Die qișaș al-anbiyā': Ein Beitrag zur arabischen Literaturgeschichte. Bonn: Universitätsdissertation.

Nelson, Kristina. 2001. The Art of Reciting the Qur'an. Cairo, New York: American University in Cairo Press.

Nesari. 2013. Wa'z mahfil. Recording 14.01.2013, Cox's Bazar. 
Orsini, Francesca. 2009. Print and Pleasure: Popular Literature and Entertaining Fictions in Colonial North India. New Delhi: Permanent Black.

Sayeedi, Delwar H. Kalima Taiyebah er Tatporjo by Allama Delwar Hossain Saidi bangla waz: Youtube. Retrieved November 1, 2015 (https://www.youtube.com/watch?v=pPX3zE7BDYE).

Siddiq, Faruk. 2012. Bangla new waz mahfil 2012 -A little 12 years old boy waz in bangla. Islmaic bangla waz of 2012. Retrieved June 16, 2016 (https://www.youtube.com/watch?v=I-aDAcuGmrg).

Silverstein, Michael. 2003. "Indexical Order and the Dialectics of Sociolinguistic Life." Language \& Communication 23(3-4):193-229.

Staal, Frits. 1979. “The Meaninglessness of Ritual.” Numen 26(1):2-22.

Stille, Max. 2014. "Islamic Non-Friday Sermons in Bangladesh.” South Asia Chronicle/SüdasienChronik 4:94-114.

Stille, Max. 2016. "Conceptualizing Compassion in Communication for Communication. Emotional Experience in Islamic Sermons (Bengali wa' $z$ mahfils)." Contributions to the History of Concepts 11(1):81-106.

Ṭhākur, Rabỉndranāth. 1367 [1960]. "Bāṃlā śabdadvaita." Pp. 371-73, in Rabindra Racanābali, edited by R. Ṭhākur: Biśwabhāratî.

Thompson, Hanne-Ruth. 2010. Bengali: A Comprehensive Grammar. London, New York: Routledge.

Tschacher, Torsten. 2001. Islam in Tamilnadu: Varia. 2. Halle (Saale): Institut für Indologie und Südasienwissenschaften.

Wilce, James M. n.d. "Diglossia, Religion, and Ideology. On the Mystification of Cross-Cutting Aspects of Bengali Language Variation.", in Proceedings of the 1995 Bengal Studies Conference, University of Chicago (http://www.lib.uchicago.edu/LibInfo/SourcesBySubject/SouthAsia/ James.1.html).

\section{NOTES}

1. This is a slightly updated version of my paper "Communities of Code-switching Connoisseurs: Multilingualism in Islamic sermons in Bangladesh" held at the $24^{\text {th }}$ conference of the European Association for South Asian Studies, 2016, for which I was awarded the Student Research Award by the European Association for South Asian Studies. I thank the EASAS as well as the many commentators of the panel "Linguistic Terrains in South Asia", later at the South Asia Colloquium at the Max-Planck-Institute at Human Development, and last but not least two great anonymous reviewers.

2. I use this simplified Roman rendering for readability. The Bengali is mostly written as oya $\bar{j}$ mäh'phil, of course relating to the Arabic/Urdu words spelled wa'z mahfil. For the transliteration, I followed the Romanization systems of the respective languages, but of course we have to keep in mind that this is somewhat artificial as the sermons were performed orally and not in writing. I however tried to follow pronunciations, and e.g. consciously transcribed the Urdu zo'e with two dots when preachers pronounced it not as an emphatic Arabic za.

3. This juxtaposition of course is only relative, as Friday sermons in turn are a complex composition of different elements. For an overview about the sermons in question here, see Stille (2014). 
4. The title of the 2013 Telugu film "Prema Ishq Kaadhal", for example, repeats the word "Love" in Telugu (Prema), Urdu/Hindi (Ishq) and Tamil (Kaadhal). I thank Imke Rajamani for pointing out this example.

5. Although different in their theoretical background, both the approaches of Iser (1978) and Fish (1970) argue for approaching reader response by textual analysis.

6. See Silverstein (2003) for a summary of and reflection upon different orders of indexicalities.

7. Of course this statement is to be taken only in comparison, and with at least a grain of salt, as shown for example by the overview provided on http://ethnologue.com/.

8. For a recent overview over the genesis and configuration of modern South Asian languages, see Harder (2016a:47f).

9. However, there are instances of English code-switching, e.g. in the diaspora in Englishspeaking countries, in relation to topics which are conventionally bound to English.

10. For a good overview warning against the pitfalls of interpretational categories see Wilce (n.d.).

11. Also the interlinkages with Arabic script used to write Bengali, Tamil, and Malayālam have to be noticed, albeit both phenomena of can occur independent of each other. On the case of Arabic script used to write Tamil, see Tschacher (2001); on the case of Malayālam, see Karassery (1995).

12. For an example of this statement, see Muneer (2015:11f).

13. On the important role ritual language might play even without the words being understood, see Staal (1979).

14. I refer to a sermon by Ābul Kāsem Nūrỉ at a boys' madrasa in 2014.

15. There continued to be an active Bangladeshi scholarship on the background of dobhāsīi which includes such seminal figures as Āh'mad Śariph, Ānisujjāmān and Asim Roy. See also the first chapter in Jalil (1999).

16. The video titled "Māolānā Deloỷār Hosen Sāidī_oỳāj”, a recording from Chittagong in 2006, was deleted from Youtube.

17. This aspect of the performance is part of a ubiquitous paratextual gesture across genres and performances. See Harder (2016b).

18. For examples from mosques, see Bassiouney (2013). The simulation of personalized communication of mass media has been extensively described in relation to Arabic TV-preachers, particularly 'Amr Khālid.

19. In a mahfil in London, a preacher uses the terms "Lovers [premik] of Allah, lover of the messenger [rasūl] and lover of the saints [ori, from wali]" to address only those aligning themselves under these Barelwi buzzwords.

20. An example for Urduized Bengali is the expression shukriya àdäy karchi as opposed to krtajña $\bar{a}$ dày karchi that is used here for uttering thanks.

21. The pronunciation here is with an emphatic $d(d)$ - the B khodā is thus Arabized phonetically.

22. One rare but prominent example for such an artificial word is of course the formula used by many preachers to test the audience's consent: “isn't that right? [țik nā bethik]". Here, the Persian prefix be is combined with the usual thik instead of negating the word by asking something like "țhik ki nā?"

23. While the Arabic figure of speech called 'itba' $\bar{a}^{\text {' }}$ borders on the phenomenon described here, it seems to be confined to emphasis and intensity. See Pellat, "Muzāwadja" Encyclopaedia of Islam, Second Edition.

24. Cf. The importance of dasya-rasa among the five rasas of the devotee is e.g. elaborated in the Caitanya caritāmṛta. See Kṛșnadāsa Kavirāja Gosvāmi, Dimock and Stewart (1999:629f).

25. Thereby pointing to a relative stability of synonymization among preachers of different ideological backgrounds.

26. This is from a yet unpublished draft by Thibaut d'Hubert, "'Give him some Khichuri': The spread of Indo-Afghan literary culture in Bengal and the Deccan (ca. 15th-17th AD)". 
27. "Poetic quality" refers to Bengali "ras laye" (Mannan's transliteration).

28. The first is the Aristotelian enthymeme, the latter the common definition from Quintilian onwards.

29. See Kane (2008) for an unfortunately unpublished dissertation on the musical aspects of this performance tradition as practiced today.

30. While it is not possible to 'prove' this, the resemblance between the final cadence of Shaykh Muhammad Siddiq al-Minshawi as transcribed by Nelson (2001:129), to the melody of the chant of Delwar Hossain Sayeedi strongly suggests a connection.

31. The dynamics of this important process have, for example, been described in relation to Indonesia by Gade (2004).

32. Such as the global advent of Egyptian Qur' anic recitation in the 1960s.

33. For examples from an important antecedent of the waz mahfils, the qisas al-anbiya $\bar{a}$, see Nagel (1967).

34. See Hansen (2016) for a related phenomenon in Urdu and Parsi theatre, the antecedent of Bollywood. For future inquiries, it would be desirable to consider the linkage of multilingual markers with those of speech registers. This interlinkage might link the pleasure described in this article with the "novel" experience in the development of South Asian prose writing, see Orsini (2009:chapter five).

35. While we can at this point only speculate about the link between scripts and performance, it is noteworthy that both Bakhtiyāīi (2003[1927]) and al Siddiki (n.d.) include different scripts. Finally, one might even ask about the aesthetic transformation taking place by the transcription of Oriental studies.

\section{ABSTRACTS}

Code-switching is a universal phenomenon of community formation. Religious speech switches between different registers and codes, expanding its possibilities. In South Asia, the pleasure of including different codes and languages is, at the same time, a characteristic of poetic messages, of popular culture and linguistic systems. This paper considers the code-switching in Islamic sermons in contemporary Bangladesh (waz mahfils), which are characterized by a stress on oral performance and communal experience. On the basis of a theoretical introduction into the terminology of code-switching and its rhetorical and poetic expansion, different levels of codeswitching in the sermons are analyzed. These range from switches between individual words (mostly from Arabic, Urdu and Bengali), to binding together of several sentences by vocal techniques. From the perspective of code-switching in performance, "formal" translation mechanisms in the sermons, most prominently translations from the Qur'ān, can be evaluated anew. As opposed to a point of view that argumentation and persuasion of the sermons are derived from the Qur' ān as a "scripture", the inclusion of Qur'anic quotations into the dynamics of multilingual code-switching and its aesthetic effects emphasizes a poetic form of evidence building on word-play and dramatic script.

\section{INDEX}

Keywords: Bangladesh, Islam, sermon, performance, code-switching, Quran, rhetoric, preaching 
AUTHOR

MAX STILLE

Max-Planck-Institute for Human Development, Berlin 